\title{
Physical exercise and metformin in the prevention of pre-eclampsia: systematic review
}

\author{
Exercício físico e metformina na prevenção a pré-eclâmpsia: \\ revisão sistemática
}

\author{
Iramar Baptistella do Nascimento (i] ${ }^{[a]}$, Mayco Morais Nunes ${ }^{[a]}$, Raquel Fleig [ib]*
}

[a] Universidade do Estado de Santa Catarina (UDESC), Florianópolis, SC, Brazil

[b] Universidade do Estado de Santa Catarina (UDESC), São Bento do Sul, SC, Brazil

\begin{abstract}
Introduction: Pre-eclampsia is a disorder that may occur during pregnancy but is still unknown and / or multifactorial causes. Objective: To verify whether physical exercise and metformin may be helpful in preventing preeclampsia. Method: This is a systematic review of the literature in PubMed / MEDLINE, Web of Science, Scopus, LILACS and Cochrane. This review followed the critiques of the PRISMA checklist. Bias assessment was used for the Cochrane Handbook for Systematical Reviews of Interventions (Version 5.1.0) for clinical trials and the Downs and Black scale for cohort and case-control studies. Results: 17 studies were within the established criteria. The subjects evaluated were: pre-eclampsia, cardiovascular metabolic factors, physiotherapeutic therapies and the effects of physical exercise and metformin on the circulatory system. Conclusion: There is a need for adapted techniques and new protocols according to the contingencies and complications of pregnancy. During pregnancy, it is suggested a greater interdisciplinarity of knowledge among professionals and that the therapy receives adjustments against the metabolic alterations of the reproductive system. In order to prevent preeclampsia, the study suggests a program of individual exercises
\end{abstract}

*IBN: PhD, e-mail: iramar.nascimento@udesc.br MMN: PhD, e-mail: mayco.nunes@udesc.br RF: MS, e-mail: raquel.fleig@udesc.br 
that include greater assistance, verification and / or comprehension of possible changes and their limits during pregnancy. As well as, the adjuvant use of metformin of $1000 \mathrm{mg} / \mathrm{d}$ in the initial phase, with the purpose of maintaining the effects of the drug due to renal clearance during pregnancy, until reaching a maximum of $1500 \mathrm{mg} / \mathrm{d}$, to avoid side effects of the drug.

Keywords: Physical Therapy Modalities. Pregnancy. Metformin. Hypertension, Pregnancy-Induced.

\section{Resumo}

Introdução: A pré-eclâmpsia é uma desordem que pode ocorrer durante a gravidez, sendo ainda de etiologia desconhecida e/ou de causas multifatoriais. Objetivo: Verificar se o exercício físico terapêutico e a metformina podem ser coadjuvantes na prevenção da pré-eclâmpsia. Método: Trata-se de uma revisão sistemática da literatura nas bases de dados PubMed/MEDLINE, Web of Science, Scopus, LILACS e Cochrane. Esta revisão seguiu os critérios do cheklist PRISMA. Na avaliação de viés utilizou-se o Cochrane Handbook for Systematical Reviews of Interventions (Version 5.1.0) para os ensaios clínicos e a escala de Downs e Black para os estudos de coorte e caso-controle. Resultados: 17 estudos estavam dentro dos critérios estabelecidos. Os temas avaliados foram: pré-eclâmpsia, fatores metabólicos cardiovasculares, terapêuticas fisioterápicas e os efeitos do exercício físico e da metformina no sistema circulatório. Conclusão: Existe a necessidade de técnicas adaptadas e novos protocolos de acordo com as contingências e intercorrências da gestação. Durante a gravidez, sugere-se uma maior interdisciplinaridade de conhecimento entre os profissionais e que a terapêtica receba ajustes de encontro às alterações metabólicas do sistema reprodutor. O estudo sugere para prevenção a pré-eclâmpsia um programa de exercícios individuais que contemplem uma maior assistência, verificação e/ou compreensão sobre as possiveis alterações e seus limites durante a gestação. Bem como, o coadjuvante uso da metformina de $1000 \mathrm{mg} / \mathrm{d}$ na fase inicial, com o propósito de se manter os efeitos do fármaco em razão da depuração renal durante a gestação, até atingir no máximo $1500 \mathrm{mg} / \mathrm{d}$, para evitar as decorrências colaterais da droga.

Palavras-chave: Modalidades de Fisioterapia. Gravidez. Metformina. Hipertensão Induzida pela Gravidez.

\section{Introduction}

Preeclampsia (PE) is a disorder that occurs during pregnancy, is characterized by generalized and heterogeneous clinical impairment, being able to manifest itself as a maternal syndrome (hypertension, proteinuria and / or different symptoms) [1]. The complexity of multisystemic diseases resulting from this disorder has become evident in the scientific literature [2]. Intercurrences such as atherosclerosis and possible endothelial changes in maternal circulation after 20 weeks of pregnancy are associated with PE [3]. This irregularity appeared in a percentage of $2 \%$ to $8 \%$ of pregnant women worldwide in 2014 and, more recent studies, have marked the changes related to microvascular dysfunctions in woman during pregnancy $[4,5]$.

Although PE still remains of unknown etiology and / or of multifactorial causes, it is worth noting that the increase of proteinuria presents itself as an important diagnostic criterion for this disease [6]. In this way, different researches in the 1990s and 2000s tend to reduce the unfavorable maternal and neonatal prognoses coming from PE. As well as the risks for cardiovascular and metabolic diseases whose affected mothers were more likely to have associations between increased proteinuria and perinatal mortality $[7,8]$.

In normal pregnancy, blood pressure (BP) tends to drop until the beginning of the second trimester and later rise until the end of pregnancy [9]. Increased renin expression during pregnancy implies pathogens related to endothelial dysfunctions, increased sensitivity to angiotensin II and norepinephrine [10]. However, among other treatments besides antihypertensive medications, corticosteroids and seizure prophylaxis, metformin hydrochloride has been gaining its autonomy and success [11 - 13]. Its main clinical practice has been used as an oral antidiabetic and as therapy in different treatments such as prediabetes mellitus, gestational diabetes mellitus (GDM), polycystic ovary syndrome (PCOS) and PE [11 - 14]. A systematic review 
study and e strong impact meta-analysis identified the use of metformin in different clinical trials with significant results for preventing PE [15].

However, nutritional and physical means of treatment gain the merits of primary recognition in events that predict PE and, when necessary, the association of drug therapies [16]. Nevertheless, due to the particularities related to vasoactive substances and the possible changes in the vessel walls in response to hemodynamic stimuli, it implies specialized knowledge, in other words, professionals trained in therapeutic dynamics and, during pregnancy, a greater comprehension and understanding of the changes in the gestational period [17].

Although most of these physiological changes in the pregnant mother occur due to hormonal variations, studies make it possible to identify certain significant complications in mothers who are overweight [18]. Research published in 2015 and 2017 discloses the adverse effects and the short and long-term consequences related to overweight in pregnancy, with PE being one of its main predictors $[19,20]$.

Prenatal exercise through a specific program requires adaptations due to the pregnancy circumstances aiming at physical conditioning according to the progression of the pregnancy cycle. Therefore, the analysis for each pregnant woman must be individualized and designed in order to avoid exhaustion [21]. The kinesiotherapy applied by the physiotherapist with the hospital team seems to need an understanding of greater references on pregnancy, meaning, the body's kinetics and its influence on physiological changes during pregnancy, once they can influence endothelial vascular growth factors and the placental level [22].

Thus, the specific knowledge of the physiotherapist working in the multidisciplinary order suggests that it is relevant in hypertensive diseases prevention and in the maternal-fetal outcomes. The present study aims to identify, based on scientific publications, how therapeutic physical exercise and metformin can be helpful in preventing preeclampsia.

\section{Method}

A systematic literature review was developed. In the course of this research, the guidelines according to the items for Systematic Review and Meta-Analysis PRISMA checklist were used [23]. This systematic review was registered with the CRD (Center for Reviews and Dissemination) international prospective registry of assessments (PROSPERO) under the number CRD 4201811722.

\section{Eligibility criteria}

Studies on cardiovascular metabolism; therapeutic guidelines with exercise in pregnancy; obstetric use of oral antidiabetics; physiological adaptations in pregnancy; perinatal complications and the incidence of PE were considered eligible. In this research there were no limitations regarding the language and year of publication. According to the pre-established protocol, the methodological characteristics of the studies were collected as follows: the search was for clinical trial studies, retrospective, prospective, case control and cross-sectional cohort studies with data from primary or secondary sources. For this study, book chapters, personal articles, editorials, letters, opinions, comments and summaries of congresses were not considered. In the literary search, the PICO strategy was applied [24]. Population: the samples should be with pregnant women aged 16 years or older. Intervention: the purpose was to collect data on the results obtained in different studies of exercise therapies and compare them with the results obtained in the prevention of PE, oral antidiabetics during pregnancy and outcomes of PE. Control: the main established comparator was the observation of exercise therapies during pregnancy and the verification of the obstetric use of oral antidiabetic metformin hydrochloride in preventing PE. In order to allow a comparison between physical exercises and obstetric treatments, studies with the use of metformin hydrochloride to prevent $\mathrm{PE}$ in obese pregnant women, gestational diabetes mellitus (GDM) were allowed, since they are unfavorable complications relevant to the predisposition of the pregnant woman to the incidence and outcomes of PE regarding the use of the drug for PCOS $[11,13,19]$. Outcomes: the reduction of PE with therapeutic physical exercises and the use of metformin hydrochloride by the obstetrician in perinatal outcomes. With this information, the idea of enabling a better conception of the possible support between the two treatments, therapeutic exercises and subsequent use of metformin, was hypothesized. 
Information sources and data collection strategies

The PubMed / MEDLINE, Web of Science, Scopus, LILACS and Cochrane databases were used. The Lilacs Virtual Health Library (DeCS) Health Science Descriptors were used to obtain the keywords. The descriptors Physical Therapy Modalities, Pregnancy, Metformin and Hypertension, Pregnancy-Induced, associated with the Boolean operators "AND" and "OR", were selected in order to obtain articles more adherent to the proposed theme.
From the initial selection of publications added to the chosen bases and the proposed criteria, a number of references were obtained after removing duplicates from 1,622 studies. A referential selection process for systematic reviews was applied, adopting the following steps: identification through the aforementioned research sites; screening by titles and abstracts; eligibility on the population; methods, relevance of the project; association data between therapies applied during pregnancy and PE incidence; therapeutics with the respective follow-ups during pregnancy and, subsequently, the inclusion of studies, with further details in the Figure 1.

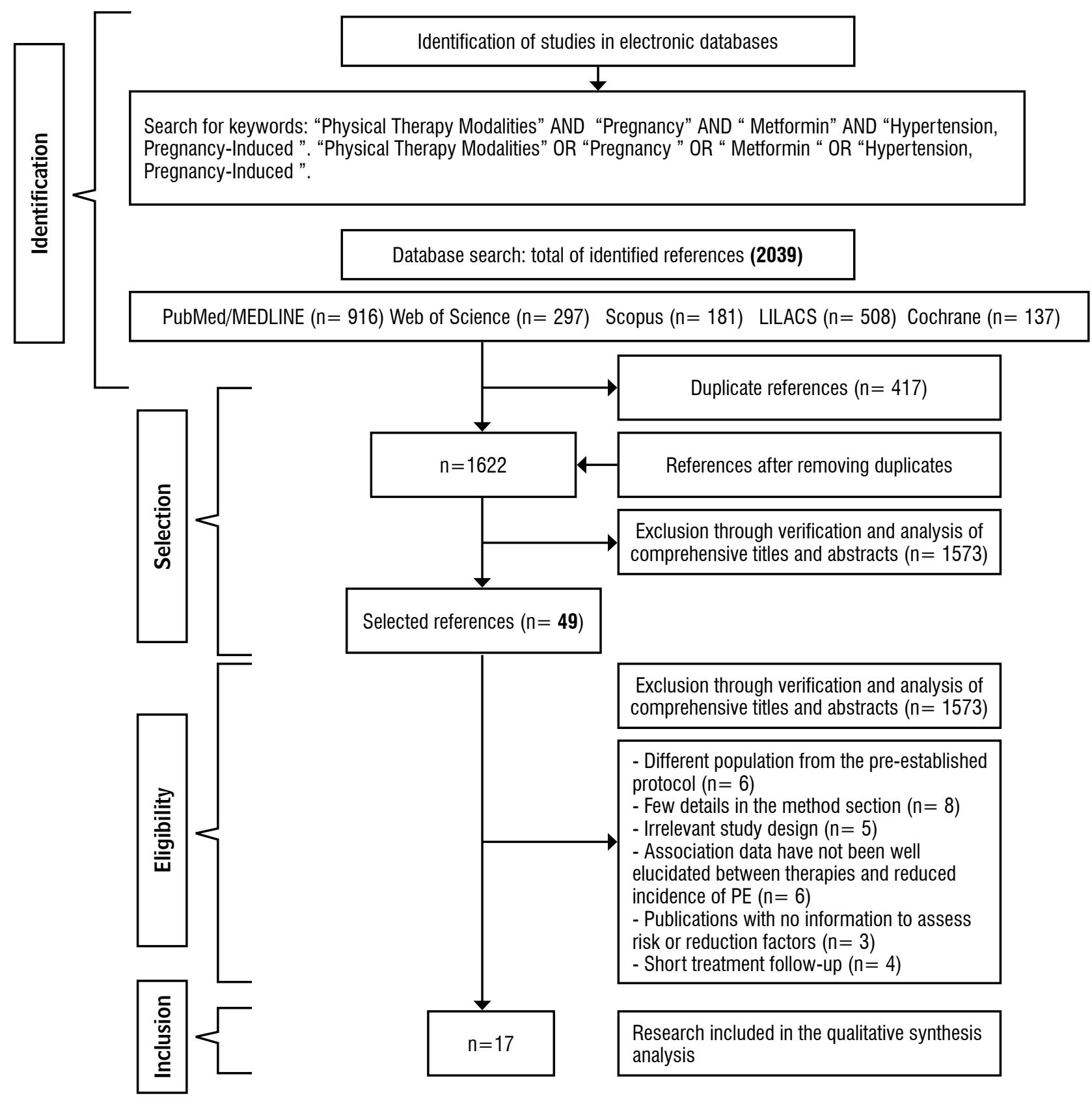

Figure 1 - Flowchart of the selection process activities through the bibliographic search diagram adapted from the PRISMA checklist. 
Selection of studies

Two authors extracted the most relevant data obtaining researches on the respective sites. The preference was given to topics related to exercise therapies and the use of metformin in pregnancy. Subsequently, the analysis was carried out independently and in case of disagreement, the three authors reviewed the priorities pre-established in the initial protocol. It is worth mentioning that any information not well clarified or due to lack of data on the characteristics in clinical trials or other studies, the authors of the journals would be contacted for further clarification.

\section{Data extraction}

Data were collected, such as author and year of publication, country of data collection, type of study, dosages and number of participants. After collecting data and findings from different studies, the objective was organizing them (Table 1).

Inclusion criteria: the research could only be in humans. In animals when the goal was to understand the hemodynamic vascular behavior or pharmacokinetic and pharmacodynamics action of metformin. In the analysis of the studies, the sample size was verified and research with the greatest impact was prioritized. It is worth mentioning that in the clinical trials researches, the interventions segment time were observed; not less than three months of follow-up for metformin; and not less than one month for therapeutic physical exercises. The drug should be during pregnancy and physical exercises during it and also studies after pregnancy with the focus of analysis on autonomic control and PE. In observational research that addressed the effects of therapeutic exercises for PE and the use of metformin in pregnancy that obtained results on the reduction or not of PE.

Table 1 - Characteristics of selected clinical trial studies with the use of metformin in pregnancy and adaptation of the Cochrane Handbook bias checking tool

\begin{tabular}{|c|c|c|c|c|c|c|}
\hline $\begin{array}{l}\text { Author and year } \\
\text { of publication }\end{array}$ & $\begin{array}{l}\text { Type of } \\
\text { study }\end{array}$ & Population and sample & $\begin{array}{c}\text { Dosage } \\
\text { and / or method }\end{array}$ & Segment & Country & $\begin{array}{c}\text { Risk of bias } \\
\text { level }\end{array}$ \\
\hline $\begin{array}{l}\text { Tertti et al. [11] } \\
(2013)\end{array}$ & $\mathrm{RCT}$ & $\begin{array}{l}217 \text { pregnant women, } \\
\text { aged } \geq 18 \text { years } \\
\text { Metformin }(n=110) \\
\text { Insulin }(n=107)\end{array}$ & $\begin{array}{l}500 \mathrm{mg} / \mathrm{d} \text { to } \\
1,000 \mathrm{mg} / \mathrm{d}\end{array}$ & $\begin{array}{l}6 \text { to } 7 \\
\text { months }\end{array}$ & Finland & Low \\
\hline $\begin{array}{l}\text { Rowan et al. [12] } \\
\text { (2008) }\end{array}$ & $\mathrm{RCT}$ & $\begin{array}{l}751 \text { pregnant women, aged } \\
\text { between } 18 \text { and } 45 \text { years } \\
\text { Metformin }(n=363) \\
\text { Insulin }(n=370)\end{array}$ & $2,500 \mathrm{mg} / \mathrm{d}$ & $\begin{array}{l}4 \text { to } 5 \\
\text { months }\end{array}$ & $\begin{array}{l}\text { New Zealand } \\
\text { and } \\
\text { Australia }\end{array}$ & Low \\
\hline $\begin{array}{l}\text { Syngelaki et al. } \\
\text { [35] (2016) }\end{array}$ & $\mathrm{RCT}$ & $\begin{array}{l}450 \text { pregnant women, } \\
\text { aged } \geq 18 \text { years } \\
\text { Metformin }(n=202) \\
\text { Placebo }(n=198)\end{array}$ & $\begin{array}{c}500 \mathrm{mg} / \mathrm{d} \\
\text { to } \\
3,000 \mathrm{mg} / \mathrm{d}\end{array}$ & $\begin{array}{l}5 \text { to } 6 \\
\text { months }\end{array}$ & $\begin{array}{l}\text { USA and United } \\
\text { Kingdom }\end{array}$ & Low \\
\hline $\begin{array}{l}\text { Chiswick et al. } \\
{[40]} \\
(2015)\end{array}$ & $\mathrm{RCT}$ & $\begin{array}{l}449 \text { pregnant women, } \\
\text { aged } \geq 16 \text { years } \\
\text { Metformin }(n=226) \\
\text { Placebo }(n=223)\end{array}$ & $\begin{array}{c}500 \mathrm{mg} / \mathrm{d} \\
\text { to } \\
2,500 \mathrm{mg} / \mathrm{d}\end{array}$ & $\begin{array}{l}5 \text { to } 6 \\
\text { months }\end{array}$ & United Kingdom & Low \\
\hline $\begin{array}{l}\text { Vanky et al. [41] } \\
(2004)\end{array}$ & $\mathrm{RCT}$ & $\begin{array}{l}40 \text { pregnant women, } \\
\text { aged between } 18 \text { and } 40 \text { years } \\
\text { Metformin }(n=18) \\
\text { Placebo }(n=22)\end{array}$ & $1,700 \mathrm{mg} / \mathrm{d}$ & $\begin{array}{c}4 \text { to } 5 \\
\text { months }\end{array}$ & Norway & Moderate \\
\hline $\begin{array}{l}\text { Vanky et al. [42] } \\
(2010)\end{array}$ & $\mathrm{RCT}$ & $\begin{array}{l}273 \text { pregnant women, } \\
\text { aged between } 18 \text { and } 42 \text { years } \\
\text { Metformin }(n=135) \\
\text { Placebo }(n=138)\end{array}$ & $2,000 \mathrm{mg} / \mathrm{d}$ & $\begin{array}{l}5 \text { to } 6 \\
\text { months }\end{array}$ & Norway & Low \\
\hline $\begin{array}{l}\text { Hameed et al. [43] } \\
\text { (2011) }\end{array}$ & $\mathrm{RCT}$ & $\begin{array}{l}57 \text { pregnant women, } \\
\text { aged } \geq 18 \text { years } \\
\text { Metformin }(n=31) \\
\text { Control group }(n=26)\end{array}$ & $2,500 \mathrm{mg} / \mathrm{d}$ & $\begin{array}{l}2 \text { to } 3 \\
\text { months }\end{array}$ & Egypt & Moderate \\
\hline $\begin{array}{l}\text { Niromanesh } \\
\text { et al. [44] } \\
\text { (2012) }\end{array}$ & $\mathrm{RCT}$ & $\begin{array}{l}\text { Pregnant women, } \\
\text { aged } \geq 18 \text { years } \\
\text { Metformin }(n=80) \\
\text { Control group }(n=80)\end{array}$ & $\begin{array}{l}500 \mathrm{mg} / \mathrm{d} \text { to } \\
2,500 \mathrm{mg} / \mathrm{d}\end{array}$ & $\begin{array}{l}4 \text { to } 5 \\
\text { months }\end{array}$ & Iran & Moderate \\
\hline
\end{tabular}

Note: RCT - Randomized Clinical Trial; USA - United States of America. 
Exclusion criteria: non-relevant scientific articles that addressed other disorders and conditions that were not aimed at cardiovascular changes, populations that were not related to pregnancy, studies that had no primary or secondary relationship with PE. Physical therapies unrelated to physical exercise during preg nancy and studies with the use of drugs other than a comparative method with metformin hydrochloride.

\section{Association measures used}

This systematic review considered studies with analysis of proportions using the Chi-square and Fischer's exact tests for the reduction of PE. Probability measures through relative risk (RR) and odds ratio (OR) were also evaluated in the studies. When possible, the $p$ value was assessed in the analyzes and confidence intervals.

\section{Assessment of the risk of bias in individual studies}

Both authors (IBN and R.F), in assessing the risk of bias in clinical trial studies, followed the guidelines of the Cochrane handbook for systematic reviews of interventions (version 5.1.0) [25]. With an adaptation of the Cochrane Handbook bias checking tool, the researchers evaluated and considered the results as follows: the level of bias corresponding to the domain (1) (selection) Generation of the random sequence, (2) (selection) Concealment of allocation, (3) (performance) Blinding of participants and professionals, (4) (detection) Blinding of evaluators of outcome, (5) (attrition) Incomplete outcomes, (6) (report) Selective outcome report, (7) (other biases) other sources of bias. Thus, it considered a low risk of bias survey when the study reached six or more of the domains categorized as low risk corresponding to The Cochrane Collaboration's tool for assessing risk of bias in randomized clinical trials; moderate, when the study reached five low risk domains; high, when the study reached at most three to four domains with low risk of bias; very high, when the study reached at most three low risk domains of the tool. Studies classified as low or moderate risk of bias were considered in this research. In case of disagreement between two surveys, a third reviewer (M.M. N.) performed the review and the choice was made by consensus among the three authors.

The authors, after using the adapted tool, performed a new check analyzing the external and internal validity, measurement bias factors, selection, confusion and power of the study in discussion and if data collection and analysis were conducted with exclusion and inclusion with a defined population with no tendentiousness. Neutrality was observed in the choice criteria, the characteristics of the populations and the strategies used.We tried to identify the confounding effects on the results, the therapeutic methods used to prevent the incidence of PE, gestational ages (GA) of pregnant women entering scientific researches, design and a comparison of the clinical characteristics of patients included in each study. Regarding the use of metformin or physical exercise therapies, the segment time was observed in the studies and / or the period in which interventions were developed in pregnant women. Consecutively, a comparative dynamic has been established between previous and more recent studies with greater impacts on the use of metformin in pregnancy and, concomitantly, therapies with physical exercises already developed to prevent $\mathrm{PE}$ and recommended practices of physical exercises in prenatal care.

Analysis and verification of results on risk ratio (RR) and odds ratio (OR) with physiotherapy and obstetric therapies with the use of oral antidiabetic metformin to confront in the discussion.

In other types of studies, such as, prospective, retrospective cohort, case control and cross-sections, the bias was assessed by the scale adapted from Downs and Black [26]. Guidance on preventive methods for gestational hypertension and PE was observed. In this way, the same research properties were maintained, evaluating the particularities, reliability, data validity and quality. For all studies, the absolute and relative values or the p-value of the chi-square test were analyzed in a comparison between the selected studies. The $\mathrm{p}$-value was evaluated for the odds ratio (OR), relative risk, absolute risk reduction (ARR). The maximum score regarding the methodological characteristics in the cohort studies was 22 points and similarly for the casecontrol studies. For cross-sectional studies, maximum of 12 points. Subsequently, a keyword citation analysis was performed. The 20 studies were then submitted to bibliometric analysis of descriptors. The objective was to evaluate the present in the selected articles. Thus, the analysis of the keywords allowed a retrospective assessment of the quality of the selection process of the articles used in this systematic review, as shown in Figure 2. 


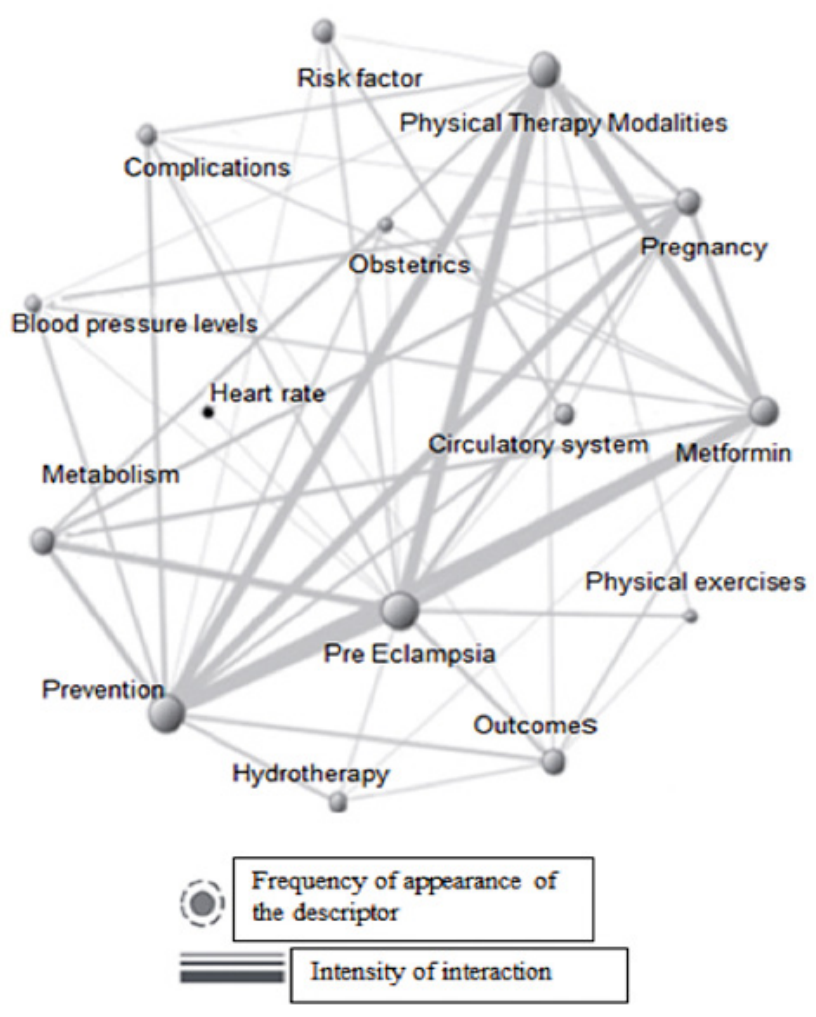

Figure 2 - Interaction analysis of the most relevant keywords. Themes evaluated for the development of the discussion

- Physiological changes in pregnancy and prophylactic predictors of preeclampsia

- Obstetric therapies with the oral antidiabetic metformin hydrochloride

- Therapies with physical exercise and performance of the physiotherapist during pregnancy

\section{Results and discussion}

The scientific studies that participated in this systematic review were found between the years 2000 and 2017. Through the selection of the database, 2039 articles were identified on the topic of interest. After removing 417 duplicate articles, 1622 articles in English, Portuguese, Spanish and German were obtained for the analysis. In sequence, a check of the most comprehensive titles and abstracts, 1537 articles were eliminated, resulting in 49 articles in the first stage of the study and eligible for the second stage of systematic review. Of the 49 studies analyzed in full, 32 were excluded for the following reasons: six studies presented a different population from the protocol pre-established in the current research; eight studies with few details in the method section; five studies with irrelevant study design; six studies whose association data were not shown between therapies and reduction in the incidence of $\mathrm{PE}$, three studies with no information to assess risk reduction or non-risk factors and four studies with short treatment follow-up.

In the present research, 17 studies showed a greater correlation with the selection criteria and objectives of this investigation, nine (52.94\%) were from clinical trials with the use of metformin during pregnancy, showing results related to the reduction of the incidence of PE using the drug with different dosages and treatment period (Table 1 ); four $(23,52 \%)$ were studies of clinical trials using exercise therapies during pregnancy and results related to SHG and PE (Table 2); three prospective cohorts $(17.64 \%)$ related to physical exercise and hypertensive outcomes in pregnancy and one (5.88\%) case control on therapeutic exercises during pregnancy and the outcomes on PE risks (Table 3).

Table 2 - Characteristics of selected clinical trial studies with the use of physical exercise therapies during pregnancy and adaptation of the Cochrane Handbook bias checking tool

\begin{tabular}{|c|c|c|c|c|c|c|}
\hline $\begin{array}{l}\text { Author and year } \\
\text { of publication }\end{array}$ & $\begin{array}{l}\text { Type of } \\
\text { study }\end{array}$ & Population and sample & $\begin{array}{l}\text { Dosage } \\
\text { and / or method }\end{array}$ & Segment & Country & $\begin{array}{l}\text { Risk of } \\
\text { bias } \\
\text { level }\end{array}$ \\
\hline $\begin{array}{l}\text { Barakat et al. [22] } \\
\text { (2011) }\end{array}$ & RCT & $\begin{array}{l}80 \text { pregnant women aged } \\
\text { between } 23-32 \text { years } \\
\text { Intervention group } \\
(n=40) \\
\text { Control group }(n=40)\end{array}$ & $\begin{array}{l}\text { Exercise program in } \\
\text { sedentary pregnant women }\end{array}$ & 7 months & Spain & Low \\
\hline $\begin{array}{l}\text { Kasawara et al. } \\
{[48]} \\
(2013)\end{array}$ & RCT & $\begin{array}{l}116 \text { pregnant women } \\
\geq 18 \text { years old } \\
\text { Intervention group } \\
(\mathrm{n}=58) \\
\text { Control group }(\mathrm{n}=58)\end{array}$ & $\begin{array}{c}\text { Physical exercise once a } \\
\text { week }\end{array}$ & $\begin{array}{l}4 \text { to } 5 \\
\text { months }\end{array}$ & Brazil & Moderate \\
\hline
\end{tabular}

(to be continued) 


\begin{tabular}{|c|c|c|c|c|c|c|}
\hline & & & & & & (conclusion \\
\hline $\begin{array}{l}\text { Pivarnik et al.[49] } \\
\text { (2003) }\end{array}$ & CT & $\begin{array}{l}16 \text { pregnant women } \\
\text { Intervention group }(n= \\
10) \\
\text { Control group }(n=6)\end{array}$ & $\begin{array}{l}\text { Programs (15 min) } \\
\text { performed at a certain heart } \\
\text { rate }\left(\mathrm{HR}: 140 \text { b. } \mathrm{min}^{-1}\right) \text {. }\end{array}$ & $\begin{array}{c}3 \text { months } \\
\text { during } \\
\text { pregnancy } \\
12 \text { weeks after } \\
\text { delivery }\end{array}$ & USA & Moderate \\
\hline $\begin{array}{l}\text { Hartman et al. [58] } \\
(2001)\end{array}$ & CT & $\begin{array}{l}32 \text { pregnant women } \\
\text { aged } \geq 18 \text { years }\end{array}$ & $\begin{array}{l}\text { Adequacy of aerobic } \\
\text { exercise in liquid } \\
\text { environment }\end{array}$ & $\begin{array}{l}3 \text { to } 4 \\
\text { months }\end{array}$ & Switzerland & Moderate \\
\hline $\begin{array}{l}\text { Domingues et al. } \\
{[61]} \\
(2015)\end{array}$ & RCT & $\begin{array}{l}639 \text { pregnant women } \\
\text { Intervention group } \\
(n=213) \\
\text { Control group }(n=426)\end{array}$ & $\begin{array}{l}\text { Proposal for different } \\
\text { exercise } \\
\text { programs }\end{array}$ & $\begin{array}{l}3 \text { months and } \\
\text { postpartum }\end{array}$ & Brazil & Low \\
\hline
\end{tabular}

Note: RCT - Randomized Clinical Trial; PE - preeclampsia; HR - heart rate; b. min $^{-1}$ - beats per minute.

Table 3 - Characteristics of selected cohort and case-control studies with physical exercises during pregnancy with a Downs and Black scale score / maximum score and relative frequency

\begin{tabular}{|c|c|c|c|c|c|c|}
\hline $\begin{array}{c}\text { Study and } \\
\text { year of } \\
\text { publication }\end{array}$ & $\begin{array}{l}\text { Type of } \\
\text { study }\end{array}$ & $\begin{array}{l}\text { Population and } \\
\text { sample }\end{array}$ & $\begin{array}{l}\text { Therapeutic exercise } \\
\text { and / or method }\end{array}$ & Segment & Country & $\begin{array}{l}\text { Escore } \\
\text { Downs Black } \\
\text { /RF (\%) } \\
\end{array}$ \\
\hline $\begin{array}{l}\text { Prevedel et al. } \\
{[46]} \\
(2003)\end{array}$ & $\begin{array}{l}\text { Prospective } \\
\text { cohort }\end{array}$ & $\begin{array}{l}60 \text { pregnant women } \\
\text { Study group }(n=22) \\
\text { Control group }(n=19)\end{array}$ & $\begin{array}{l}\text { Hydrotherapy } \\
\text { program }\end{array}$ & 4 to 5 months & Spain & $\begin{array}{c}11 / 22 \\
\mathrm{RF}: 72.72\end{array}$ \\
\hline $\begin{array}{l}\text { Sorensen et al. } \\
{[50]} \\
(2003)\end{array}$ & $\begin{array}{l}\text { Case } \\
\text { control }\end{array}$ & 386 pregnant women & $\begin{array}{l}\text { Qualitative and } \\
\text { quantitative data on your } \\
\text { usual walking pace }\end{array}$ & First 5 months & Brazil & $\begin{array}{c}17 / 22 \\
\text { RF: } 77.27\end{array}$ \\
\hline $\begin{array}{l}\text { Magnus et al. } \\
{[59]} \\
(2008)\end{array}$ & $\begin{array}{l}\text { Prospective } \\
\text { cohort }\end{array}$ & $\begin{array}{l}\text { Data set of } 59,573 \\
\text { pregnant women }\end{array}$ & $\begin{array}{l}\text { Estimation of PE } \\
\text { according to physical } \\
\text { activity }\end{array}$ & $\begin{array}{l}\text { Collection } \\
\text { between 14- } \\
22 \text { weeks of } \\
\text { gestation }\end{array}$ & Norway & $\begin{array}{c}18 / 22 \\
\text { RF: } 81.81\end{array}$ \\
\hline $\begin{array}{l}\text { Scholten et al. } \\
{[60]} \\
(2014)\end{array}$ & $\begin{array}{l}\text { Prospective } \\
\text { study }\end{array}$ & $\begin{array}{l}44 \text { pregnant women } \\
\text { Study group }(n=24) \\
\text { Control group }(n=20)\end{array}$ & $\begin{array}{c}\text { Estimation of } \\
\text { autonomic control } \\
\text { from PE. } \\
\text { Physical activity } \\
\text { program }\end{array}$ & $\begin{array}{l}\text { Submitted to } \\
\text { the exercise } \\
\text { program } \\
6-12 \text { months } \\
\text { postpartum }\end{array}$ & Netherlands & $\begin{array}{c}14 / 22 \\
R F: 63.63\end{array}$ \\
\hline
\end{tabular}

Note: PE - preeclampsia; $n$ - number of patients; RF - relative frequency.

\section{Bias assessment results in included studies}

Of the 17 studies included in the selection process, 13 studies of clinical trials were within the standards, in other words, with the reduced standards of bias using the manual guidelines for systematic reviews of interventions. Of the studies with evaluated clinical practices, seven (53\%) studies had a low risk of bias and six studies $(46 \%)$ had a moderate risk of bias.

Regarding other types of studies, only four of them were within the pre-established standards of the protocol; three prospective cohort studies and one casecontrol study. The absolute and relative values were observed in the Downs and Black scale. The absolute and relative numbers found were at least $63.63 \%$ and at most $81.81 \%$, indicating an average score of $73.85 \%$, with further details in Table 3.
Physiological changes in pregnancy and prophylactic predictors of preeclampsia

In the gestational period, significant changes in such a short time require a specialized professional understanding due to the various physiological and endocrine adjustments aimed at an ideal environment for the fetus, with a sequence of events not fully elucidated. Among others, the expressiveness related to changes pertinent to the circulatory system, as well as the body weight on the lumbar region, the pressures on the pelvic floor and the most intense nervous compressions in the third trimester of pregnancy [27].

The fertilized egg needs to adapt to the internal environment and the pregnant woman's body becomes altered due to the repercussions of this phenomenon. Consequently, local and systemic changes occur [28]. In 
this way, the woman presents her own conditions during her pregnancy with a series of changes in functioning and in body shapes. Therefore, the gestation period has circumstances that cannot be classified as normal from a physiological point of view, nor abnormal under the clinical aspect, but must be considered as a special clinical condition [29].

The benefits of multidisciplinary programs during pregnancy aim to provide pregnant women with a prognosis of well-being and a physical and psychological balance during and after labor [30]. One of the main causes of maternal-fetal outcomes of morbidity and mortality is PE [31]. Although there is a hypothesis that rest would be the most suitable practice for pregnant women with a propensity to hypertension, there is not enough evidence in the bibliography to recommend such conduct [32]. Establishing baselines and specified treatments for PE prevention has become a demand to be overcome, since there is no single biomarker that can be clinically useful for predicting recurrent PE [33].

Dynamic or static exercise applied to a risk group containing obese pregnant women seems to require further knowledge, of a greater essence to adaptations, mainly on the understanding between muscle contraction and cardiovascular response. A study shows that vascular and cardiac changes are referring to physiological behavior related to training intensity or technique applied during pregnancy [32]. In another study, direct and indirect predictors of myocardial oxygen consumption were verified, which can be parameters for cardiovascular risks during strength and aerobic exercise according to intensity parameters [34].

In addition to the intervention regarding changes in the pregnant woman's lifestyle, innovative therapies should be developed with the purpose of delineating and reducing risk factors before conception [32]. Thus, specific therapies should be analyzed with the same parameters and particularities of the variables that influence cardiovascular dysfunctions during the gestational period, especially in overweight pregnant women, with more frequent monitoring during prenatal care and a follow up of fetal growth with ultrasound beside the hospital interdisciplinary team $[32,35]$. Therefore, the path to a better interpretation of $\mathrm{PE}$ and its prevention seems to be in an understanding of the possible changes and their limits.

As well as the scope of the factors that are associated with the growth of the uterus and subsequent risks from the modified lipid metabolism, since factors are strongly associated with the occurrence of PE [36].
Currently, different clinical presentations and genetic imperfections have become challenging in face of the diagnosis during pregnancy. In this scenario, it is worth noting the little understanding of complications in pregnant women of a genetic and intracellular nature, such as, for example, mitochondrial diseases. On the subject, a recent study pointed out that mitochondria dysfunctions at the placental level suggest the pathogenesis of PE [37]. However, physical exercise regulates placental mitochondria and concomitantly increases its biogenesis at the muscular level [38]. Nevertheless, other proposals with better quality of life can be developed, since the expressive blood pressure level and the cardiac output value can be reduced with exercise.

While some researchers point out in the bibliography the direction for different treatments, others suggest the urgent need for randomized clinical trials to identify whether therapies with kinesiotherapy activities programs and / or antihypertensive medication may or may not be specifically prophylactic to unfavorable perinatal outcomes and reduction of high rates of maternal and fetal morbidity and mortality $[31,33,36]$.

Obstetric therapies with oral antidiabetic metformin hydrochlorides

Current obstetric studies with the administration of oral antidiabetics have shown a reduction in PE through its action on the receptors corresponding to the soluble vascular endothelial growth factor- 1 and soluble endogline, favoring improvements in endothelial and antigenic disorders [15, 39]. Authors of a meta-analysis carried out in 2017 identified, in clinical studies, that metformin suggests a greater attenuation of the soluble FMS-like tyrosine kinase-1 (sFlt-1) angiogenic factorse endogline acting on the receptors responsible for the soluble vascular endothelial growth factor- 1 and soluble endogline, conceiving improvements in vascular dysfunctions [15].

A strong impact study pointed out metformin hydrochloride with dosages of up to $3000 \mathrm{mg} / \mathrm{d}$, in a followup of 12 to 18 weeks of administration as a supporting alternative for reducing $\mathrm{PE}$, since the drug acts with an insulin-sensitizing agent pointing out the reason reduced chances for $\mathrm{PE}(\mathrm{OR}=0.24 ; 95 \% \mathrm{CI} 0.10-0.61)(\mathrm{p}<0.01)$ [34]. In contrast, another study of clinical practices in non-diabetic pregnant women over a period of 15 to 16 weeks using metformin with dosages of $2500 \mathrm{mg} / \mathrm{d}$ until childbirth showed results in agreement with the EMPOWaR judgment on the lack of efficacy of metformin 
hydrochloride in reducing the incidence of $\mathrm{PE}(\mathrm{OR}=2.39$; 95\% CI 0.61-9.36) $(\mathrm{p}=0.21)(\mathrm{p}>0.01)$ [40].

A study in pregnant women with PCOS with an entry period between 5 to 12 weeks of gestation and administration of $1700 \mathrm{mg} / \mathrm{d}$ did not show any difference regarding the reduction in the incidence of PE. Similarly, another study with the same treatment follow-up with $2000 \mathrm{mg} / \mathrm{d}$ dosage did not find any difference between the intervention group and the placebo in preventing PE $[41,42]$. After these results in a publication in the following year, other authors with a dosage of 1000 $\mathrm{mg} / \mathrm{d}$ increased to $2500 \mathrm{mg} / \mathrm{d}$ according to the mother's gestational body mass index (BMI), did not reduce the $P E$ values $(p=0.58)(p>0.01)$ [43].

In pregnant women diagnosed with GDM the results regarding absolute and relative numbers showed more significant results with the use of metformin. In a study with pregnant women between 20 and 33 weeks of pregnancy they started treatment with a dose of 500 $\mathrm{mg}$ and according to the increase in GI they reached $2500 \mathrm{mg} / \mathrm{d}$, the numbers were $5.5 \%$ in the metformin group versus $7 \%$ in pregnant women who administered insulin [12]. In a study with pregnant women between 20 and 33 weeks of pregnancy they started treatment with a dose of $500 \mathrm{mg}$ and according to the increase in GI they reached $2500 \mathrm{mg} / \mathrm{d}$, the values were $5.5 \%$ in the metformin group versus $7 \%$ in pregnant women who administered insulin. In 2012, researchers with an initial dosage of $500 \mathrm{mg} / \mathrm{d}$ after three days with an increase of $1000 \mathrm{mg} / \mathrm{d}$ until the end of pregnancy, pointed to a PE incidence of $4.6 \%$ in 110 pregnant interventions versus $9.4 \%$ of 107 control pregnant women [11]. Another study with 80 pregnant women in each group, metformin and insulin, with $500 \mathrm{mg}$ twice daily and after two weeks thereafter increased to $1000 \mathrm{mg} / \mathrm{d}$ and subsequently $2,500 \mathrm{mg} / \mathrm{d}$ until reaching the appropriate level of mothers' glycemic patterns. The resulting values were $6.3 \%$ metformin versus $8.7 \%$ insulin in the incidence of PE [44].

There is a need for a more careful analysis of the dosages of the drug to be applied, since during pregnancy the renal clearance becomes higher and can subsequently be eliminated during the gestational period reducing the functionality of the drug [45]. Another issue is the side effects and, due to the impairments after obtaining PE, the future mother must be treated before pregnancy, with the purpose of preserving her from possible pharmacological reactions. [33].
Therapies with physical exercise and performance of the physiotherapist during pregnancy

Therapeutic physical exercise has parameters of preferential quality in numerous treatments, however hydrotherapeutic activity has not demonstrated significant effects in pregnant women who had practiced it during 20 weeks of gestation. In the intervention and control groups, hydrotherapy favored adequate maternal metabolic and cardiovascular adaptation to pregnancy [46]. Among other benefits, physical exercise increases the body's consumption of glucose causing negative regulation of the genes encoded in the MO25 protein and positive regulation of the AMPK encoding genes that activate the transducer of regulatory protein CREB 2 (TORC2) which has the function of controlling protein activities and inhibiting liver conversions of "aglicanos" compounds (pyruvate), reducing gluconeogenesis [47].

However, there is a contradictory idea regarding the results of physical exercises in pregnancy. A moderate program with exercise therapy in the first, second and third semester improves maternal perception of health status [22]. Researchers compared group of pregnant women who practiced exercise with sedentary ones. At 25 and 36 weeks of gestation and at 12 weeks postpartum, both groups were assessed through an ergometer cycle. Exercise practitioners reached higher loads for the same heart rate. Cardiorespiratory responses are better for a physically active woman and are maintained during pregnancy [48].

On the complications of hypertension, in a study with 116 pregnant women, 58 performed physical exercise with an exercise bike supervised by a specific professional, once a week, for 30 minutes, with controlled intensity (heart rate $20 \%$ above resting values). There were no differences between groups regarding maternal results related to $\mathrm{PE}(\mathrm{OR}=0.86$; 95\% $\mathrm{CI} 0.32-2.12)$ ( $p>0.01$ ) [49]. Another study, in which there was a dynamic with therapeutic exercises, showed an impact by reducing risk factors with a drop in heart rate before, during and after exercise. [31]. Programs developed by professionals with specific training in the areas of Physiotherapy stand out. Exercises monitored with walking, women who exercise and practice hydrotherapy showed improvements in the blood circulation of pregnant women and changes in their lifestyles $[31,50]$. 
The objective of physical therapy interventions is to reduce blood pressure levels before the pregnancy period, since aerobic exercise is contraindicated in pregnant women who have changes in blood pressure levels [51].

In the study of Souza et al. [52], the authors emphasize the idea that the physiotherapist is responsible for guiding changes in the pregnant woman's life habits in order to reduce risks. Researchers in 2016 identified that pregnant women who participated in any physical activity at the beginning of the first trimester of pregnancy achieved a reduction of up to $35 \%$ on the risk of acquiring hypertensive disease, or even with a favorable prognosis and greater benefits when practiced in the year prior to pregnancy [53].

However, other proposals with better quality of life can be developed, since particularities and / or specificities about blood pressure levels, certain effects and their contraindications already seem to be explicit in scientific bibliography. Among several, the decrease in the expressive pressure level and the value of cardiac output with low intensity exercise due to the drop in heart rate (HR). A study, published in 2017, showed from the IV Brazilian Guidelines on Hypertension that the heart rate should be between $60 \%$ and $80 \%$ of the maximum or the maximum oxygen consumption between $50 \%$ and $70 \%$, reducing blood pressure levels [54]. Another study confirmed physical exercise therapy as a fundamental quality of treatment and, if necessary, the use of drugs to avoid unfavorable blood pressure changes [55].

Different types of exercises can be used and adapted for prenatal care [30]. A Research has concluded that inactive women should be encouraged to start prenatal exercise programs involving aerobic and muscle conditioning. The guidelines on aerobic exercise in pregnancy should be carried out regularly (minimum 2 days per week), and the duration of exercise can be gradually and progressively increased from 15 to approximately 30 minutes per day throughout the second trimester and, concomitantly, the intensity of the exercise should be prescribed and monitored using target heart rate zones modified and combined with the method on assessment of perceived exertion (RPE), being that any external work performed, will not cause changes due to pregnancy and / or increased gestational age [28].

Although there is an idea of rest to prevent PE, authors of a case-control research found that women who engaged in some regular physical activity during pregnancy compared with inactive women indicated reduced odds ratio for $\mathrm{PE}(\mathrm{OR}=0,65 ; 95 \% \mathrm{CI} 0.43-0.99)$
( $p<0.01$ ) [50]. Physical exercise has a strong association with the reduction of GDM by decreasing insulin resistance, which is related to hypertensive disorders in pregnancy [56].

Yeo et al. [57] in a randomized clinical trial comparing walking exercises with stretching, found that regular stretching exercises increased the level of transferrin, that is, an endogenous antioxidant marker in women at risk for PE.

As for aquatic exercises, hydrostatic pressure stimulates specific receptors by adjusting hormonal and neural reflexes, stimulating natriuresis and diuresis, controlling systolic and diastolic pressures [58]. Scholars in a comparison between pregnant women at rest and when performing exercises in water and on land identified that immersion did not change systolic and diastolic pressure in both environments. However, the study showed a reduction in blood pressure levels when pregnant women were submitted to water exercise in comparison to activities on land [58]. Authors in a prospective cohort estimated the risk of PE according to the frequency of physical activity. The study verified the results of other case-control surveys that suggested recreational physical activity to prevent $\mathrm{PE}$ and, according to the results, they concluded that recreational exercises may be more limited and only in non-obese pregnant women [59]. Another program after pregnancy showed greater control of the cardiovascular system in women with PE [60].

Therefore, the specific therapeutic activities to be developed for the prophylaxis of gestational hypertensive syndromes (GHS) do not seem to be elucidated in the scientific literature, although some movements against contraindications are already known, such as the supine posture after the fourth month, the performance of valsalva maneuvers during resisted exercise and ballistic movements should be avoided [28]. Thus, a better interdisciplinarity between physiotherapists, physical educators and doctors is necessary in order to develop therapeutic exercises that allow the stability of the HR in each stage of its dynamics and the analysis of its variability. In such situation, that is, during pregnancy, presenting itself contingently during the changes and complications of the gestational period [55].

Recent year research presents alternatives with physical therapies during pregnancy, however, with little targeting to the hypertensive problems of pregnant women [61]. There are alternatives for greater knowledge on this topic; hypertensive control parameters are already evident in sports science to assess 
the autonomic management of $\mathrm{CF}$, both at rest and in moderate intensity exercises [62]. Therefore, this indicator shows consistency, efficacy and must be weighed according to the changes and eventualities of pregnancy, while a noticeable absence of a more sophisticated biomarker, protocols and technological means still prevails in order to better understand the prevention of PE.

The current study presented some limitations, such as the reduced number of interventional researches with the use of physiotherapy techniques in the prevention of GHS, as well as the reduced number of studies that recorded the behavior of blood pressure (BP) in a sequential manner during gestational ages (GA). Another limiting factor was the restricted approach with treatment modalities in order to reduce the occurrence of PE. Likewise, there were few analyzes and / or followup after the second trimester on the outcomes related to the pressure levels of pregnant mothers who performed physiotherapy preventions. Therefore, we could have better parameters on the possible implementation or suggestions for new therapies and future prognosis. The strength of this research was the number of obstetric studies, their concerns and interventions with metformin hydrochloride. The laboratory, observational and review studies on predictors of PE and its complications showed similarity that added to the enrichment of the present research. Another positive factor was the recognition by obstetricians and the possibility of comparative analysis regarding statistical results on PE. In this context, the need for a specialized professional to better understand the reductions on occurrence of PE and to assist researchers for new contemporary studies aimed at hypertensive diseases during pregnancy was better understood.

\section{Conclusion}

There is a need for adapted techniques and new protocols according to the contingencies and complications of pregnancy. During pregnancy, it is suggested a greater interdisciplinarity of knowledge among professionals and that the therapy receives adjustments against the metabolic alterations of the reproductive system. In order to prevent preeclampsia, the study suggests a program of individual exercises that include greater assistance, verification and / or comprehension of possible changes and their limits during pregnancy. As well as, the adjuvant use of metformin of $1000 \mathrm{mg} / \mathrm{d}$ in the initial phase, with the purpose of maintaining the effects of the drug due to renal clearance during pregnancy, until reaching a maximum of $1500 \mathrm{mg} / \mathrm{d}$, to avoid side effects of the drug.

\section{References}

1. Jim B, Sharma S, Kebede T, Acharya A. Hypertension in pregnancy: a comprehensive update. Cardiol Rev. 2010;18(4):178-89.

2. Shah DM. Preeclampsia: new insghts. Curr Opin Nephrol Hypertens. 2007;16(3):213-20.

3. Liu CM, Cheng PJ, Chang SD. Maternal complications and peri-natal outcomes associated with gestational hypertension andsevere preeclampsia in Taiwanese women. J Formos Med Assoc. 2008;107(2):129-38.

4. Ahmed R, Dunford J, Mehran R, Robson S, Kunadian V.Preeclampsia and future cardiovascular risk among women: a review. J Am Coll Cardiol. 2014;63(18):1815-22.

5. Stanhewicz AE, Jandu S, Santhanam L, Alexander LM. Increased angiotensin II sensitivity contributes to microvascular dysfunction in women who have had preeclampsia. Hypertension. 2017;70(2):382-9.

6. Piña MS, Villasmil ER, Montilla JM, Bolívar JS, Cepeda DJ, Villasmil NR. Valor predictivo de la proteinuria en 24 horas en la resultante neonatal de las preeclámpsicas. Clin Invest Ginecol Obstet. 2017;44(3):119-24.

7. Ushida T, Macdonald-Goodfellow SK, Quadri A, Tse MY, Winn LM, Pang SC, et al. Persistence of risk factors associated with maternal cardiovascular disease following aberrant inflammation in rat pregnancy. Biol Reprod. 2017;97(1):143-52.

8. Al RA, Baykal C, Karacay O, Geyik PO, Altun S, Dolen I. Random urine protein- creatinine ratio to predict proteinuria innew-onset mild hypertension in late pregnancy. Obstet Gynecol. 2004;104(2):367-71.

9. Burti JS, Andrade LZ, Caromano FA, Ide MR. Adaptações fisiológicas do período gestacional. Rev Fisioter Bras. 2006;7(5):375-80.

10. Shah DM. Role of the renin - angiotensin system in the pathogenesis of preeclampsia. J Physiol. 2005;288(4):614-25. 
11. Tertti K, Ekblad U, Koskinen P, Vahlberg T, Ronnemaa T. Metformin vs. insulin in gestational diabetes. A randomized study characterizing metformin patients needing additional insulin. Diabetes Obes Metab. 2013;15(3):246-51.

12. Rowan JA, Hague WM, Gao W, Battin MR, Moore MP. Metformin versus insulin for the treatment of gestational diabetes. N Engl J Med. 2008;358(19):2003-15.

13. Nawaz FH, Khalid R, Naru T, Rizvi J. Does continuous use ofmetformin throughout pregnancy improves pregnancyoutcomes in women with polycystic ovarian syndrome? J Obstet Gynaecol Res. 2008;34(5):832-7.

14. Butalia S, Gutierrez L, Lodha A, Aitken E, Zakariasen A, Donovan L. Short- and long-term outcomes of metformin compared with insulin alone in pregnancy: a systematic review and meta-analysis. Diabet Med. 2017;34(1):27-36.

15. Romero R, Erez O, Huttemann M, Panaitescu B, Condeagudelo A, Pacora P, et al. Metformin, the aspirin of the 21st century: its role in gestational diabetes, prevention of preeclampsia and cancer, and the promotion of longevity. Am J Obs Gynecol. 2017;217(3):282-302.

16. Alfadhli EM. Gestational diabetes mellitus. Saudi Med J. 2015;36(4):399-406.

17. Zygmunt M, Herr F, Munstedt K, Lang U, Liang OD. Angiogenesis and vasculogenesis in pregnancy. Eur J Obs Gynecol Reprod Biol. 2003;110(Suppl 1):S10-8.

18. Silva JC, Karoline I, Willeman M, Salles WB. Obesidade materna e suas consequências na gestação e no parto : uma revisão sistemática Maternal obesity and its consequences in pregnancy and birth outcomes : a systematic review Resumo Abstract. Femina. 2014;42(3):135-40.

19. Barton JR, Joy SD, Rhea DJ, Sibai AJ, Sibai BM. The influence of gestational weight gain on the development of gestational hypertension in obese women. Am J Perinatol. 2015;32(7):615-20.

20. Truong YN, Yee L M, Caughey AB, Cheng YW. Weight gain in pregnancy: does the Institute of Medicine have it right? Am J Obs Gynecol. 2015;212(3):362.e1-8.

21. Skow RJ, King EC, Steinback CD, Davenport MH. The influence of prenatal exercise and pre-eclampsia on maternal vascular function. Clin Sci (Lond). 2017;131(17):2223-40.
22. Barakat R, Pelaez M, Montejo R, Luaces M, Zakynthinaki M. Exercise during pregnancy improves maternal health perception: A randomized controlled trial. Am J Obstet Gynecol. 2011;204(5):402.e1-7.

23. Galvão TF, Pansani TSA HD. Principais itens para relatar Revisões sistemáticas e Meta-análises: A recomendação PRISMA. Epidemiol Serv Saude. 2015;24(2):335-42.

24. Santos CMCS, Pimenta CAM, Nobre MRC. A estratégia PICO para a construção da pergunta de pesquisa e busca de evidências. Rev Latino-Am Enfermagem. 2007;15(3):508-11.

25. Higgins JPT, Green S. Cochrane handbook for systematic reviews of interventions. Version 5.1.0. The Cochrane Collaboration; 2011 [cited 2018 May 3]. Available from: http://www.cochrane-handbook.org.

26. Downs SH, Black N. The feasibility of creating a checklist for the assessment of the methodological quality both of randomised and non-randomised studies of health care interventions. J Epidemiol Commun Health. 1998;52(6):377-84.

27. Carvalho MECC, Lima LC, Terceiro CAL, Pinto DRL, Silva MN, Cozer GA, et al. Lombalgia na gestação. Rev Bras Anesthesiol. 2017;67(3):266-70.

28. Wolfe LA, Davies GAL. Canadian guidelines for exercise in pregnancy. Clin Obstet Gynecol. 2003;46(2):488-95.

29. Dempsey JC, Williams MA, Leisenring WM, Shy K, Luthy DA. Maternal birth weight in relation to plasma lipid concentrations in early pregnancy. Am J Obstet Gynecol. 2004;190(5):1359-68.

30. Canesin KF, Amaral WN. Atuação fisioterapêutica para diminuição do tempo do trabalho de parto: revisão de literatura. Femina. 2010;38(8):429-33.

31. Finkelstein L, Bgeginski R, Tartaruga MP, Alberton CL, Kruel LFM. Comportamento da freqüência cardíaca e da pressão arterial, ao longo da gestação, com treinamento no meio líquido. Rev Bras Med Esporte. 2006;12(5):376-80.

32. Barton JR, Sibai BM. Prediction and prevention of recurrent preeclampsia. Obstet Gynecol. 2008;112(2):359-72.

33. Amorim MMR, Souza ASR. Prevenção da pré-eclâmpsia baseada em evidências. Femina. 2009;37(1):47-52. 
34. Farinatti PTV, Assis BFCB. Estudo da freqüência cardíaca, pressão arterial e duplo- produto em exercícios contraresistência e aeróbico contínuo. Rev Bras Ativ Fis Saude. 2000;5(2):5-16.

35. Syngelaki A, Nicolaides KH, Balani J, Hyer S, Akolekar $\mathrm{R}$, Kotecha R, et al. Metformin versus Placebo in Obese Pregnant Women without Diabetes Mellitus. N Engl J Med. 2016;374(5):434-43.

36. Noronha Neto C, Souza ASR, Amorim MMR. Tratamento da pré-eclâmpsia baseado em evidências. Rev Bras Ginecol Obstet. 2010;32(9):459-68.

37. Chiaratti MR, MalikS, Diot A, Rapa E, Macleod L, Morten $\mathrm{K}$, et al. Correction: Is Placental Mitochondrial Function a Regulator that Matches Fetal and Placental Growth to Maternal Nutrient Intake in the Mouse? PLoS One. 2017;12(2):e0171795.

38. Oliveira MR, Dessen MA. Alteracoes na rede social de apoio durante a gestacao e o nascimento de filhos. Estud Psicol. 2012;29(1):81-8.

39. Moraes Filho RS, Ribeiro JP. Variabilidade da frequência cardíaca como instrumento de investigação do sistema nervoso autônomo em condições fisiológicas e patológicas. Rev HCPA. 2005;25(3):99-106.

40. Chiswick C, Reynolds RM, Denison F, Drake AJ, Forbes $S$, Newby DE, et al. Effect of metformin on maternal and fetal outcomesin obese pregnant women (EMPOWaR): a randomised, double-blind, placebo-controlled trial. Lancet Diabetes Endocrinol. 2015;3(10):778-86.

41. Vanky E, Salvesen KÅ, Heimstad R, Fougner KJ, Romundstad P, Carlsen SM. Metformin reduces pregnancy complications without affecting androgen levels in pregnant polycystic ovary syndrome women: results of a randomized study. Hum Reprod. 2004;19(8):1734-40.

42. Vanky E, Stridsklev S, Heimstad R, Romundstad P, Skogøy $\mathrm{K}$, Kleggetveit $\mathrm{O}$, et al. Metformin versusplacebo from first trimester to delivery in polycystic ovarysyndrome: a randomized, controlled multicenter study. J Clin Endocrinol Metab. 2010;95(12):448-55.

43. Hameed A, Shreif H, Mowafy H. The role of continuing metformin therapy during pregnancy in the reduction of gestational diabetes and improving pregnancy outcomes in women with polycystic ovary syndrome. Middle East Fertil Soc J. 2011;16(3):204-8.
44. Niromanesh S, Alavi A, Sharbaf FR, Amjadi N, Moosavi S, Akbari S. Metformin compared with insulin in the management of gestational diabetes mellitus: a randomized clinical trial. Diabetes Res Clin Pract. 2012;98(3):422-9.

45. Hughes RC, Gardiner SJ, Begg EJ, Zhang M. Effect of pregnancy on the pharmacokinetics of metformin. Diabet Med. 2006;23(3):323-6.

46. Prevedel TTS, Calderon IMP, De Conti MH, Consonni EB, Rudge MVC. Repercussões maternas e perinatais da hidroterapia na gravidez. Rev Bras Ginecol Obstet. 2003;25(12):53-9.

47. Pacheco C, Santos LHP, Alves JO, Queiros NA, Soares PM, Ceccattol VM. Regulação gênica da via ampk pelo exercício físico: revisão sistemática e análise in silico. Rev Bras Med Esporte. 2017;23(4):327-34.

48. Kasawara KT, Burgos CS, Nascimento SL, Ferreira NO, Surita FG, Pinto e Silva JL. Maternal and perinatal outcomes of exercise in pregnant women with chronic hypertension and/or previous preeclampsia: a randomized controlled trial. ISRN Obstet Gynecol. 2013;2013:857047.

49. Pivarnik JM, Ayres NA, Mauer MB. Effects of maternal aerobic fi tness on cardiorespiratory responses to exercise. Med Sci Sports Exerc. 2003;25(9):993-8.

50. Sorensen TK, Williams MA, Lee IM, Dashow EE, Thompson ML, Luthy DA. Recreational physical activity during pregnancy and risk of preeclampsia. Hypertension. 2003;41(6):1273-80.

51. Barton JR, Sibai BM. Prediction and prevention of recurrent preeclampsia. Obstet Gynecol. 2008;112(2 Pt 1):359-72.

52. Souza VFF, Dubiela A, Serrão Jr NF. Efeito do tratamento fisioterapêutico na pré-eclâmpsia. Fisioter Mov. 2010;23(4):663-72.

53. Bianco-Miotto T, Blundell C, Buckberry S, Chamley L, Chong S, Cottrell E, et al. IFPA meeting 2015 workshop report I: placental mitochondrial function, transport systems and epigenetics. Placenta. 2016;48(1):3-6.

54. Monteiro MF, Sobral Filho FD. Exercício físico e controle da pressão arterial. Rev Bras Med Esporte. 2004;10(6):513-6. 
55. Rodriguez-Lopez M, Wagner P, Perez-Vicente R, Crispi F, Merlo J. Revisiting the discriminatory accuracy of traditional risk factors in preeclampsia screening. PLoS One. 2017;12(5):178528.

56. Genest DS, Falcao S, Gutkowska J, Lavoie JL. Impact of exercise training on preeclampsia: potential preventive mechanisms. Hypertension. 2012;60(5):1104-9.

57. Yeo S, Davidge S, Ronis DL, Antonakos CL, Hayashi R, O'Leary S. A comparison of walking versus stretching exercises to reduce the incidence of preeclampsia: a randomized clinical trial. Hypertens Pregnancy. 2008;27(2):113-30.

58. Hartman S, Kolble N, Rake A, Bung P, Huch A, Ruch R. Aqua fit during pregnancy: maternal and fetal hemodynamic responses during rest, immersion and exercise. Geburtshilfe und Frauenheilkunde. 2001;61(12):977-82.
59. Magnus P, Trogstad L, Owe KM, Olsen SF, Nystad W. Recreational Physical Activity and the Risk of Preeclampsia: A Prospective Cohort of Norwegian Women. Am J Epidemiol. 2008;168(8):952-7.

60. Scholten RR, Thijssen DJ, Lotgering FK, Hopman MT, Spaanderman ME. Cardiovascular effects of aerobic exercise training in formerly preeclamptic women and healthy parous control subjects. Am J Obstet Gynecol. 2014;211(5):516.e1-11.

61. Domingues MR, Bassani, DG, Silva SG, Coll CVN, Silva BGC, Hallal PC. Physical activity during pregnancy and maternal-child health (PAMELA): study protocol for a randomized controlled. Trials. 2015;16:227.

62. Hedelin RG, Kentta U, Wiklund U, Benriksson-Larsén K. Short term overtraining: effects on performance, circulatory responses, and heart rate variability. Med Sci Sport Exerc. 2000;32(8):1480-4.

Received: $12 / 23 / 2017$

Recebido: 23/12/2017

Approved: 03/19/2020

Aprovado: $19 / 03 / 2020$ 